Original Research Article

\title{
Bio-Management of root-knot nematode (Meloidogyne incognita) in tomato (Lycopersicon esculeutum L.)
}

Pant, Hemlata and Verma, Jyoti

Department of Zoology, C.M.P. P.G. College, University of Allahabad, Allahabad (U.P.) India

Corresponding Author: panthemlata8@gmail.com; dr.jyotiverma@ymail.com

\section{A R T I C L E I N F O}

Received: 11 August 2018 | Accepted: 25 September 2018 | Published Online: 31 December 2018

DOI: $10.31786 / 09756272.18 .9 .2 .209$

EOI: 10.11208/essence.18.9.2.209

Article is an Open Access Publication.

This work is licensed under Attribution-Non Commercial 4.0 International

(https://creativecommons.org/licenses/by/4.0/)

(C)The Authors (2018). Publishing Rights @ MANU_ICMANU \& ESSENCE_-IJERC.

\section{A B S T R A C T}

Tomato (Lycopersicon esculeutum L.) is one of the most important vegetables grown in India. It is grown for the domestic market under both rains fed and irrigated conditions. Due to the high demand for tomato in the domestic market and for processing, farmers have extensively adopted high yielding varieties and modern technologies like greenhouse production to ensure year round production and increase production. Intensive tomato cultivation in India has resulted in build-up of soil borne diseases, especially root - knot nematodes. Various bio-control agents' viz. Trichoderma virde Paecilomyces lilacinus and Beauvaria bassiana were used for experimental purpose. The result showed that Trichoderma virde was very effective for the management of rootknot namatode followed by Paecilomyces lilacinus and Beauvaria bassiana respectively. Maximum growth parameters shoot length $(58.25 \mathrm{~cm})$, root-length $(19.75 \mathrm{~cm})$, fresh shoot weight $(15.37 \mathrm{~g})$, fresh root weight $(2.37 \mathrm{~g})$ and number of fruits $(2.25)\}$ were observed in Trichoderma virde followed by P.lilacinus s shoot length $(53.00 \mathrm{~cm})$, root-length $(13.00 \mathrm{~cm})$, fresh shoot weight $(11.75 \mathrm{~g})$, fresh root weight $(2.12 \mathrm{~g})$ and number of fruits $(1.7)\}$ and Beauvaria bassiana \{shoot length $(49.75 \mathrm{~cm})$, root length $(8.75 \mathrm{~cm})$, fresh shoot weight $(9.25 \mathrm{~g})$, fresh root weight $(1.25 \mathrm{~g})$ and number of root-knot was noted in T. viride (17.25), P. lilacinus (18.50) and B. bassiana (24.50) respectively).

\section{K E Y W O R D S}

Bio-control | Management Root-Knot Nematode | Tomato.

\section{I T A T I O N}

Pant, Hemlata and Verma, Jyoti (2018): Bio-Management of root-knot nematode (Meloidogyne incognita) in tomato (Lycopersicon esculeutum L.). ESSENCE Int. J. Env. Rehab. Conserv. IX (1): $60-63$. 


\section{Introduction}

Plant parasitic nematodes are small microscopic roundworms which live in the soil and attack the roots of plants. Crop production problems induced by nematodes therefore generally occur as a result of root dysfunction, reducing rooting volume and foraging and utilization efficiency of water and nutrients. Many different genera and species of nematodes can be important to crop production. Tomato (hycopersicon esculentum) is an important vegetable crop is seriously affected by root-knot nematode (Sasser and Carter, 1985). Bio-control agent's particularly nematode destroying fungi are common and abundant in both natural and agricultural soil (Jatala, 1986 and Pandey et al., 2003).

Bio-control agents have got some inherent advantages of being safe, host specific efficiencies, environmental friendly and long lasting. Despite the significant advantages of bio pesticide there are some other factors which have reduced their practical effectiveness and commercial exploitation (Ganguli et al., 1994). A number of bio-control agents have been found effective against nematodes. Mankau (1990), Alam (1990). Keeping this view in mind the present investigation was carried out. The agriculturist are taking interest in developing biopesticides that are pest specific, nontoxic to human, less expensive and safe for the environment (Suman and Dikshit, 2010).

\section{Materials and Methods}

Experiment was conducted in C.M.P. P.G. College, Allahabad (U.P.) during 2018-19. Sixteen pots were taken for experimental purpose. The six inch earthen pots were sterilized with formalin \& filled with sterilized soil. Seven days old seedlings of tomato variety 'Kanchan' were planted and after seven days 1000 newly hatched larva from egg masse of Meloidogy incognita (extracted from tomato plants) were pipette and inoculated into three inch deep hole near the base of the plant in each pot and 5000 spores of $\mathrm{T}$. viride, P. lilacinus and B. bassiana were also inoculated with the help of pipet in plant zone. Plants were irrigated normally. At senescence stage of the crop observation was taken viz. shoot length, root-length, fresh shoot weight, fresh root weight, number of fruits and root-knot. T. viride, P. lilacinus and B. bassiana were multiplied in nutrient broth at $25^{\circ} \mathrm{C}$ for 15 days under stationary condition. Fungal met along with culture filtrate was sterilized and $500 \mathrm{ml}$. sterile distilled water was used inoculation in tomato plant. Data of observation was computed as per the analysis of variance test of completely randomized block design.

\begin{tabular}{|c|c|c|c|c|c|c|}
\hline Treatment & $\begin{array}{c}\text { Shoot } \mathbf{( c m )} \\
\text { length }\end{array}$ & $\begin{array}{c}\text { Root length } \\
\text { (cm) }\end{array}$ & $\begin{array}{c}\text { Fresh shoot } \\
\text { weight (g) }\end{array}$ & $\begin{array}{c}\text { Fresh root } \\
\text { weight (g) }\end{array}$ & $\begin{array}{c}\text { Number of } \\
\text { root-knot }\end{array}$ & $\begin{array}{c}\text { Number of } \\
\text { fruits }\end{array}$ \\
\hline T. virids & 58.25 & 19.75 & 15.37 & 2.37 & 17.25 & 2.25 \\
\hline B. bassiana & 49.75 & 8.75 & 9.25 & 1.25 & 18.50 & 1.50 \\
\hline P. lilacinus & 63.00 & 13.00 & 11.75 & 2.12 & 24.50 & 1.75 \\
\hline Control & 38.50 & 11.00 & 11.12 & 0.87 & 55.00 & 1.00 \\
\hline $\mathrm{CD}(\mathrm{P}=0.05)$ & 7.78 & 7.27 & - & 1.072 & 16.64 & - \\
\hline $\mathrm{F} \%(\mathrm{P}=0.05)$ & $\mathrm{S}$ & $\mathrm{S}$ & $\mathrm{NS}$ & $\mathrm{S}$ & $\mathrm{S}$ & $\mathrm{NS}$ \\
\hline
\end{tabular}

Table: 1. Influence of T. viride, $P$. lilacinus and B. bassiana on the growth parameters, number of fruits and number of root-knot. 


\section{Result and Discussion}

Observation showed that all the treatments viz. T. viride, P. lilacinus and $B$. bassiana increase plant growth parameters, number of fruits and reduced number of root knot over control. T. viride also found to be the most effective among all the treatments. Maximum plant growth parameters were found in application of T. viride, P. lilacinus and B. bassiana respectively. Minimum number of knots was also found in case of $\mathrm{T}$. viride, $\mathrm{P}$. lilacinus and B. bassiana respectively.

Maximum reduction of root-knot and higher plant growth parameters were observed in $\mathrm{T}$. viride may be due to the presence of higher concentration of toxic chemical such as 'viridin, production of volatile and nonvolatile antibiotics and release enzyme during decomposition. T. viride is also acts as biofertilizer. Similar observation made by Dennis and Webster 1971; Das and Padhi, 1998; Singh et al., 2000; Javed et al., 2008. P. lilacinus also decrease root-knot and increase plant growth parameters due to the production of 'paccilotoxin' and 'lilacin' antibiotic and egg parasitic nature of M. incognita. Reduction of root-knot and increase plant growth parameters was also observed in B. bassiana due to secretion of toxic chemical such as 'beauverin' and may be also its egg parastic nature. This is supported by the findings of (Barbercheket et al., 1991).

The study is in line with the findings of various authors on the effect of Trichoderma on F. oxysporum. Ramezani, (2010) found that soil treated with $\mathrm{T}$. harzianum reduced the disease by 92\% while. Mwangi et al., (2011) documented that $\mathrm{T}$. harzianum when applied to tomatoes increased the height and dry root weight.

Tomato (Lycopersicon esculeutum L.) is one of the most important vegetables grown in India. It is grown for the domestic market under both rainfed and irrigated conditions. Due to the high demand for tomato in the domestic market and for processing, farmers have extensively adopted high yielding varieties and modern technologies like greenhouse production to ensure year round production and increase production. Intensive tomato cultivation in India has resulted in buildup of soil borne diseases, especially root - knot nematodes in greenhouses where monoculture and limited crop rotation are practiced

\section{Acknowledgement}

The authors are thankful to the Principal, CMP PG College, University of Allahabad, and Allahabad for providing necessary facilities to complete the work.

\section{References}

Alam, M. M. (1990): Nematode destroying fungi. In: Nematode biocontrol aspects and prospects (Eds) Jairajpur et al. CBS publ. and Dist. Pvt. Ltd., New Delhi, 57-59.

Barberchek, M. E. and Kaya, H. K. (1991): Competitive interaction between nematode and Beauveria bassiana in soil borne larvae of Spodoptera exigue. Envium. Entomol, 20: 707-712.

Das, B. and Padhi. N. N. (1998): Relative efficacy of neemproducts against root knot nematode on tomato. Indian Journal of Nematology, 28: 163-167.

Dennis, C. and Webster, J. (1971): Antogonistic properties of species groups of Trichodemol: Production of non volatile antibiotics. Trans. Br. Mycol. 506, 57: 25-39.

Ganguli, A. K.; Somasekhar, N. and Dasgupta, D. R. (1994): Molecular approaches for management of nematode disease of crop plant, current nematol, 5(1): 83-108.

Gupta, S. and Dikshit, A. K. (2010): Biopesticides: An eco-friendly approach for pest control, Journal of Biopesticides, 3(1): $186-188$.

Jatala, P. (1986): Bio-Control of plant parasitic nematodes. Ann. Rev. Phytopathol, 24: 453-489.

Javed, N.; Gowen, S. R.; Inam-ul-Haq, M.; Shainab, F. and Pembroke, B. (2008): Efficacy of neem (Azadirachta indica) 
formulations on biology of root - knot nematodes (Meloidogyne javanica) on tomato. Crop Protection, 27: 36-43.

Mankau, R. (1990): Biological control of nematode pest by natural enemic, Ann. Rev. Phytopathol, 18: 415-440.

Mwangi, M.; Monda, E.; Okoth, S. and Jefwa, J. (2011): Innoculation of tomato seedlings with Trichoderma harzianum and Arbuscular mycorrhizal Fungi and their effect on growth and control of wilt in tomato seedlings. Brazilian Journal of Microbiology 42: 508 - 513.

Pandey, G.; Pandey, R. K. and Pant, H. (2003): Effect of different levels of $T$. viride against root-knot nematode in click-pea, Ann. Pl. Prot. Sci., 11 (22): 409-410.

Pant, H. and Pandey. G. (2001): Efficacy of bio control agents for management of root- knot nematode on chickpea. Ann. P1. Prot. Sci., 9(1): 157-158.

Ramezani, H. (2010): Antagonistic effects of Trichoderma spp. against Fusarium oxysporum f.sp.lycopersici causal agent of tomato wilt. Plant Protection Journal, 2(1):167-173.

Sasser, J. N. and Carter, C. C. (1985): An Advanced treatise on Meloidogyne. Vol. (1). Biology and control. North Carolina, Plant pathology, N.C. State University and U.S.A.J.D., 422.

Singh, J.; Mojumder, P. V. and Singh, R. (2000): Effect of Nimbin, $U$ coat $(R)$ and modified neem oil $(\mathrm{R})$ as urea coating on phytonematodes associated with carrot. In.Proceedings of National Congress on Centenary of Nematology in India. I.A.R.I. New Delhi. 5-7 Dec.2001. (abs). 